\title{
Comparison of three sources of inocula for predicting apparent digestibility of ruminant feedstuffs
}

\author{
Alfredo E.S. BorbA*, Pedro J.A. CorreiA, Jorge M.M. FernandeS, \\ Anabela F.R.S. BORBA
}

University of the Azores, Department of Agrarian Sciences, Animal Nutrition, 9700 Angra do Heroísmo, Azores, Portugal

(Received 4 October 1999; accepted 11 July 2001)

\begin{abstract}
In the present study, gas production of three sources of inocula rumen liquor from fistulated sheep, rumen liquor from slaughtered cattle, and a suspension of sheep faeces, were evaluated to predict the apparent digestibility of ruminant feedstuffs. The highest gas production was obtained with rumen liquor from slaughtered cattle, and the lowest $(P<0.05)$ with the suspension of sheep faeces. The relationship between gas production and in vivo apparent digestibility was determined on 24 samples of graminaceous (oats (Avena sativa L.), Italian ryegrass (Lolium multiflorum L.), perennial ryegrass (Lolium perenne L.) and maize (Zea mays L.)) at three stages of growth, and on fresh and ensiled forages. The best results for predicting in vivo digestibility were obtained with green forages and sheep rumen liquor. Correlations were not significant for silages $(P>0.05)$.
\end{abstract}

gas production / sources of inocula / in vivo digestibility / alternative methods

Résumé - Comparaison de trois sources d'inoculum pour prédire la digestibilité in vivo des fourrages chez le ruminant. La capacité de production de gaz de différentes sources d'inoculum a été évaluée dans cet essai pour prédire la digestibilité apparente des fourrages chez le ruminant. Trois sources d'inoculum ont été choisies : du jus de rumen de moutons fistulés, du jus de rumen de bovins abattus, prélevé à l'abattoir et une suspension de fèces de moutons. Au total, 24 échantillons de graminées ont été utilisés : avoine, ray-grass d'Italie, ray-grass anglais et maïs, à trois stades de développement, sous forme de fourrages verts et d'ensilages. Les résultats ont montré que la production de gaz a été la plus élevée avec le jus de rumen de bovin et la plus basse $(P<0,05)$ avec la suspension de fèces de mouton. Les relations entre la production de gaz et la digestibilité in vivo, mesurée sur six moutons adultes, mâles, alimentés ad libitum, ont été examinées et ont permis de vérifier que les meilleurs résultats pour prédire la digestibilité in vivo ont été obtenus avec les fourrages verts et le jus de rumen de moutons. Pour les ensilages, les corrélations n'ont pas été significatives $(P>0,05)$

production de gaz / sources d'inoculum / digestibilité in vivo / méthodes alternatives

* Correspondence and reprints

Tel.: 351295 204540; fax: 351295 332605; e-mail: borba @ notes.angra.uac.pt 


\section{INTRODUCTION}

The traditional method for measuring gas production, proposed by Menke et al. [19] has the disadvantage of requiring fresh inocula from permanently fistulated animals, and evaluating gas production over 24 hours. In order to avoid these inconveniences, several authors have proposed alternative methods [1, 16, 17, 27]. The advantages of these techniques are to not use surgically modified animals, to simplify the methods and to make a significant contribution to the welfare of laboratory animals.

Khazaal et al. [14,15] reported that gas production kinetics described by the equation $\mathrm{p}=\mathrm{a}+\mathrm{b}\left(1-\mathrm{e}^{-\mathrm{ct}}\right)$ [22] could be used to predict the digestibility and intake of forages. The works of Blümmel and Ørskov [2] and Herrero et al. [12] demonstrated, respectively, that the feed intake of forages and metabolisable energy of Kikuyu grass can be evaluated from in vitro gas production measurements.

In our laboratory, we measured gas production using three sources of inocula [11]: rumen fluid from fistulated sheep (traditional method), rumen fluid from slaughtered animals and a sheep faeces suspension. We also tested the same sources of inocula in order to predict the in vivo apparent digestibility [4]. In order to confirm the results obtained in these studies, in the present work we determined the kinetics of gas production with the three sources of inocula and the effect of increasing incubation times from 24 to $96 \mathrm{~h}$.

\section{MATERIALS AND METHODS}

\subsection{Plant material, animals and diets}

The forages used in the experiment $(n=24)$ were oats (Avena sativa L.), Italian ryegrass (Lolium multiflorum L.), perennial ryegrass (Lolium perenne L.) and maize (Zea mays L.), all at three stages of growth. The material had a known chemical composition and in vivo digestibility (Tab. I). All of them were gramineous, and both fresh and ensiled material were analysed.

Oats $(\mathrm{O})$ were harvested at the 5 th leaf (L), boot (B) and at the milky kernel (M) stages. Italian ryegrass (I) was harvested at the appearance of the 4th leaf (L), with 5\% of the ear $(\mathrm{F})$ and $100 \%$ of the ear $(\mathrm{H})$. Perennial ryegrass $(\mathrm{P})$ was harvested at the 4th leaf (F), 5\% ear (F) and the $100 \%$ ear $(\mathrm{H})$ stages. Maize $(\mathrm{M})$ was harvested with the kernels at the early milk (E), soft (S) and hard dough $(\mathrm{H})$ stages. All forages were analysed as both fresh $(\mathrm{F})$ and ensiled $(\mathrm{E})$. The fodder was dried at $65^{\circ} \mathrm{C}$ and grounded to $1 \mathrm{~mm}$.

Six adult male sheep with body weights of approximately $15 \mathrm{~W}^{0.75}$ were used per treatment for the in vivo digestibility

Table I. Mean data for forage composition.

\begin{tabular}{lcccccc}
\hline Forage & $n$ & $\begin{array}{c}\mathrm{DM} \\
\mathrm{g} \cdot \mathrm{kg}^{-1}\end{array}$ & $\mathrm{CP}$ & $\begin{array}{c}\mathrm{g} \cdot \mathrm{kg}^{-1} \mathrm{DM} \\
\mathrm{NDF}\end{array}$ & $\mathrm{ADF}$ & $\begin{array}{c}\mathrm{DMD} \\
\mathrm{g} \cdot \mathrm{kg}^{-1} \mathrm{DM}\end{array}$ \\
\hline Oats $^{1}$ & 6 & $141-349$ & $68-190$ & $476-598$ & $331-384$ & $514-665$ \\
Italian ryegrass $^{2}$ & 6 & $119-216$ & $134-256$ & $499-636$ & $264-407$ & $564-712$ \\
Perennial ryegrass $^{3}$ & 6 & $149-233$ & $121-255$ & $403-656$ & $234-413$ & $493-742$ \\
Maize $^{4}$ & 6 & $208-449$ & $71-91$ & $495-539$ & $265-339$ & $555-638$
\end{tabular}

${ }^{1}$ Borba \& Ramalho Ribeiro [6]; ${ }^{2}$ Borba \& Ramalho Ribeiro [4]; ${ }^{3}$ Borba \& Ramalho Ribeiro [7]; ${ }^{4}$ Borba and Ramalho Ribeiro [5].

Note: $\mathrm{n}$ - Number of observations; DM - Dry matter; CP - Crude protein; NDF - Neutral detergent fibre; ADF

- Acid detergent fibre; DMD - Dry matter digestibility. 
determinations. The digestibility trials lasted 21 days: a 14-day adaptation period and a 7 -day collection period. The animals were fed ad libitum.

\subsection{Gas production procedure}

Gas production was measured as described by Menke et al. [19]. Two hundred mg of sampled dry matter was weighed in triplicate and placed in a glass syringe to which $30 \mathrm{~mL}$ of a mixture of rumen liquor (Menke medium mixture) was added and kept in $\mathrm{CO}_{2}$. Subsequently the glass syringe was incubated at $39 \pm 0.5^{\circ} \mathrm{C}$ in an electrically heated isothermal oven equipped with a rotor, which rolled continuously at 1-2 rpm. Gas production was measured at $4,8,12$, $24,48,72$ and 96 hours after the onset of incubation. Differences in the composition and activity of the rumen liquor were controlled by nine parallel measurements, a blank test, and incubation of a roughage and a concentrate standard.

Rumen liquor was obtained from the sheep $(n=3)$ via a fistula. The animals had free access to good quality hay $(17 \%$ crude protein) and water and were fed $200 \mathrm{~g} \cdot \mathrm{d}^{-1}$ of concentrate with $19 \% \mathrm{CP}$.

The inocula source reported by Nicolic' et al. [21] was also employed. Rumen contents were removed from six healthy cattle immediately after slaughter and stored in thermolagged containers. After straining through four layers of gauze, the rumen liquor was mixed with the Menke medium mixture solution and saturated with $\mathrm{CO}_{2}$. The use of a high number of donor animals reduced the variability of the microbial activity of the inocula.

Data for gas production were fitted to the exponential equation proposed by Ørskov and McDonald [22]:

$$
\mathrm{p}=\mathrm{a}+\mathrm{b}\left(1-\mathrm{e}^{-\mathrm{ct}}\right)
$$

in which $\mathrm{p}$ represents gas production at time $(\mathrm{t})$, and $\mathrm{a}, \mathrm{b}$ and $\mathrm{c}$ represent constant values in the exponential equation.
The other source of inocula was that proposed by El Shaer et al. [10]. Fifty grams of sheep faeces were collected within $1 \mathrm{~h}$ of voiding from three sheep with free access to good quality hay (17\% crude protein) and water, and also fed $200 \mathrm{~g} \cdot \mathrm{d}^{-1}$ of concentrate with $19 \%$ crude protein. Faeces were macerated and mixed with $50 \mathrm{~mL}$ of Menke medium mixture solution previously saturated with $\mathrm{CO}_{2}$. The mixture was subsequently filtered after being made up to $300 \mathrm{~mL}$ by adding buffer solution. The $\mathrm{pH}$ of the suspension was adjusted to 6.8 using Menke medium mixture.

\subsection{Statistical analysis}

Values for total gas production after 96 hours were submitted to an analysis of variance on the basis of three methods of incubation, four species, three growth stages and two methods of preservation. Nine individual measurements were taken, giving 648 results and the degrees of freedom for error (576) were based upon the number of measurements and their interactions, according to the published method proposed by Steel and Torrie [25].

Simple and multiple regression analysis were used to investigate the relationship between in vivo digestibility and the variables of gas production with the three sources of inocula.

\section{RESULTS AND DISCUSSION}

The variance analysis of the results of gas production at $96 \mathrm{~h}$ for the three methods of incubation, four species, three growth stages and two methods of conservation are presented in Table II.

The gas production using cattle rumen liquor was significantly greater $(P<0.05)$ than that using the sheep rumen liquor, which was significantly greater $(P<0.05)$ than that using the sheep faeces suspension. 
Table II. Variance analysis of the results of gas production obtained by the three methods of incubation, the four species, the three growth stages and two methods of conservation.

\begin{tabular}{lcc}
\hline & $n$ & $96 \mathrm{~h}$ gas production $(\mathrm{ml}) \cdot 200 \mathrm{mg}^{-1} \mathrm{DM}$ \\
\hline Method (A) & & \\
$\quad$ Rumen liquor from sheep & 216 & $41.63 \mathrm{~b}$ \\
$\quad$ Rumen liquor slaughtered cattle & 216 & $38.92 \mathrm{c}$ \\
Suspension of sheep faeces & 216 & 0.467 \\
SE & & \\
Forages (B) & & \\
Oats & 162 & $42.51 \mathrm{c}$ \\
Italian ryegrass & 162 & $37.34 \mathrm{a}$ \\
Perennial ryegrass & 162 & $40.22 \mathrm{~b}$ \\
Maize & 162 & $52.64 \mathrm{~d}$ \\
SE & & 0.539 \\
Growth stages (C) & & \\
1 & & $42.60 \mathrm{a}$ \\
2 & 216 & $44.84 \mathrm{~b}$ \\
3 & 216 & $42.09 \mathrm{a}$ \\
SE & 216 & 0.467 \\
Conservation (D) & & \\
Fresh & & $45.25 \mathrm{~b}$ \\
Ensiled & 324 & 0.381 \\
SE & 324 &
\end{tabular}

Note: $\mathrm{n}$ - Number of observations; SE - Standard error; $\mathrm{a}, \mathrm{b}, \mathrm{c}, \mathrm{d}-$ Within the same row, means displaying the same letter do not differ significantly $(P<0.05)$.

Gas production from the oats was higher than that from perennial ryegrass which was higher than that from the Italian ryegrass. Gas production from maize was significantly higher than that from the other forages. Gas production was significantly greater from materials at the intermediate growth stage (due to the highest content of fermentable carbohydrates) than at earlier or later stages and greater from fresh than from ensiled material (Tab. II), probably due to a reduction in $\mathrm{pH}$ that can decrease ruminal methanogenesis [13].

The increase in gas production obtained with liquor from slaughtered cows, does not agree with the results obtained by Gonçalves and Borba [11], at 24 hours incubation time. This can easily be explained by the fact that the feeding of the liquor donor cows is unknown, and could vary. Although we used liquor from six cows to reduce variability of the inocula microbial activity, in fact we introduced a variation source.

Gas production constants, obtained by the methodology described by McDonald [18], can be found in Table III, for the three sources of inocula. In a first analysis, the r.s.d. of the method that uses sheep rumen liquor, was lower than the r.s.d. from the other two experiments. These results are in accordance with what was observed in variance analysis (Tab. II), in which the potential gas production (b value) was lower with the method that used sheep rumen liquor than the method that used rumen liquor from slaughtered cows, which was greater than that in which the sheep faeces suspension was used. 
Table III. Gas production characteristics defined by the equation $\mathrm{p}=\mathrm{a}+\mathrm{b}\left(1-\mathrm{e}^{-\mathrm{ct}}\right)$, using the three sources of inocula.

\begin{tabular}{|c|c|c|c|c|c|c|c|c|c|c|c|c|}
\hline \multirow[b]{2}{*}{ Feeds } & \multicolumn{4}{|c|}{ Rumen liquor from sheep } & \multicolumn{4}{|c|}{ Rumen liquor from bovine } & \multicolumn{4}{|c|}{ Sheep faecal suspension } \\
\hline & $\mathrm{a}$ & $\mathrm{b}$ & $\mathrm{c}$ & rsd & a & $\mathrm{b}$ & $\mathrm{c}$ & rsd & a & $\mathrm{b}$ & $\mathrm{c}$ & rsd \\
\hline OLF & -6.11 & 47.92 & 0.0497 & 1.39 & -6.75 & 54.10 & 0.0513 & 2.28 & -4.10 & 59.06 & 0.0177 & 4.41 \\
\hline OLE & -5.71 & 44.71 & 0.0455 & 1.56 & -4.76 & 51.91 & 0.0484 & 2.30 & -9.57 & 54.37 & 0.0204 & 4.17 \\
\hline OBF & -6.01 & 50.41 & 0.0553 & 1.22 & -6.89 & 56.12 & 0.0534 & 1.99 & -10.99 & 57.62 & 0.0206 & 3.96 \\
\hline OBE & -3.17 & 40.24 & 0.0457 & 1.18 & -2.08 & 47.12 & 0.0443 & 1.51 & -4.37 & 57.68 & 0.0163 & 3.35 \\
\hline OMF & -1.14 & 43.56 & 0.0426 & 0.84 & -2.14 & 57.15 & 0.0426 & 1.73 & -2.12 & 54.49 & 0.0142 & 2.33 \\
\hline OME & -3.24 & 45.35 & 0.0350 & 1.02 & -4.17 & 51.30 & 0.0469 & 2.68 & -3.41 & 65.90 & 0.0134 & 3.19 \\
\hline ILF & -6.64 & 40.66 & 0.0438 & 1.57 & -9.42 & 47.13 & 0.0519 & 2.20 & -4.99 & 42.74 & 0.0159 & 2.21 \\
\hline ILE & -5.72 & 41.83 & 0.0477 & 1.90 & -6.81 & 47.57 & 0.0539 & 2.18 & -11.10 & 51.90 & 0.0182 & 3.48 \\
\hline IFF & -6.52 & 50.75 & 0.0481 & 1.42 & -7.66 & 50.40 & 0.0485 & 2.24 & -5.35 & 60.61 & 0.0169 & 4.65 \\
\hline IFE & -4.66 & 46.80 & 0.0429 & 1.72 & -5.82 & 50.78 & 0.0476 & 2.61 & -5.90 & 58.29 & 0.0154 & 4.21 \\
\hline IHF & -2.84 & 43.59 & 0.0377 & 1.21 & -4.95 & 54.64 & 0.0472 & 2.62 & -2.04 & 63.16 & 0.0114 & 3.67 \\
\hline IHE & -4.72 & 38.45 & 0.0357 & 1.24 & -14.05 & 44.71 & 0.0444 & 0.96 & -6.21 & 55.47 & 0.0080 & 0.92 \\
\hline $\begin{array}{l}\text { InL } \\
\text { PLF }\end{array}$ & -3.91 & 48.66 & 0.0583 & 0.94 & -6.10 & 55.98 & 0.0664 & 1.83 & -4.03 & 50.85 & 0.0268 & 3.19 \\
\hline PLE & -2.78 & 38.44 & 0.0441 & 0.80 & -0.97 & 47.73 & 0.0571 & 1.43 & -1.45 & 50.73 & 0.0174 & 2.29 \\
\hline PFF & -7.09 & 50.41 & 0.0566 & 1.41 & -5.30 & 59.81 & 0.0508 & 1.53 & -4.41 & 47.42 & 0.0238 & 4.60 \\
\hline PFE & -5.74 & 44.80 & 0.0430 & 1.77 & -5.30 & 52.96 & 0.0483 & 2.35 & -4.70 & 56.08 & 0.0181 & 4.02 \\
\hline PHF & -4.01 & 40.86 & 0.0274 & 1.43 & -3.66 & 45.64 & 0.0385 & 1.61 & -2.99 & 49.09 & 0.0117 & 2.90 \\
\hline PHE & -4.51 & 38.13 & 0.0332 & 1.53 & -5.97 & 46.23 & 0.0399 & 1.77 & -3.13 & 61.48 & 0.0105 & 2.77 \\
\hline MEF & 0.48 & 54.53 & 0.0640 & 1.60 & -5.19 & 67.50 & 0.0623 & 1.19 & -1.60 & 58.70 & 0.0303 & 2.01 \\
\hline MEE & -5.32 & 49.59 & 0.0485 & 1.03 & -7.18 & 63.63 & 0.0459 & 1.80 & -6.26 & 60.50 & 0.0200 & 2.74 \\
\hline MSF & -2.32 & 52.97 & 0.0615 & 1.25 & -11.19 & 73.67 & 0.0634 & 2.12 & -3.50 & 48.31 & 0.0306 & 1.21 \\
\hline MSE & -0.49 & 46.05 & 0.0575 & 1.48 & -8.10 & 64.03 & 0.0518 & 2.09 & -2.23 & 54.45 & 0.0322 & 1.50 \\
\hline MHF & -3.06 & 53.26 & 0.0613 & 1.46 & -8.93 & 76.98 & 0.0530 & 1.60 & -1.26 & 52.11 & 0.0287 & 1.05 \\
\hline MHE & -6.47 & 53.09 & 0.0854 & 1.20 & -8.73 & 65.13 & 0.0577 & 2.40 & -3.88 & 46.92 & 0.0397 & 1.09 \\
\hline
\end{tabular}

Oats (O) were harvested at the 5th leaf (L), boot (B) and at the milky kernel (M) stages. Italian ryegrass (I) was harvested at appearance of the 4th leaf (L), with 5\% of ear $(\mathrm{F})$ and $100 \%$ ear $(\mathrm{H})$. Perennial ryegrass $(\mathrm{P})$ was harvested at the 4 th leaf $(\mathrm{F}), 5 \%$ ear $(\mathrm{F})$ and the $100 \%$ ear $(\mathrm{H})$ stages. Maize $(\mathrm{M})$ was harvested with the kernels at the early milk (E), soft (S) and hard dough (H) stages. All forages were analysed both fresh (F) and ensiled (E) 
With the method that used suspension of sheep faeces, the lower values of $c$ indicate that when the suspension of sheep faeces was used as source of inocula, gas production had not ceased by the end of the trial. More trials must be conducted, namely with this source of inocula.

The nutritive value of forages is subject to considerable variation, especially when harvested at different stages of growth and subjected to different methods of conservation. Therefore, a simple, reliable and inexpensive technique that predicts the nutritive value of the forages is very important.

We observed that the method that used sheep rumen liquor (Tab. IV) displayed a significant correlation, both with simple regression and $a+b+c$ to multiple regressions. The values found were lower than the ones related by Khazaal et al. [14]. With the method that used rumen liquor from slaughtered cows (Tab. IV), significant results were achieved just with the constant, in the case of simple regressions, and with $(\mathrm{a}+\mathrm{b})+\mathrm{c}$ in the case of multiple regressions. The method did not give results as good as those described by Nicolic' et al. [21], for in vitro digestibility. With the method that used suspension of sheep faeces (Tab. IV), significant correlations were obtained only with $(\mathrm{a}+\mathrm{b})$, on the contrary to that put forth by El Shaer et al. [10] and Omed et al. [23] for in vitro digestibility.

When green forages and silages were separated, it was possible to verify that the method that used sheep rumen liquor gave good results on in vivo apparent digestibility prediction of green gramineae, especially

Table IV. Relationship of in vivo DM apparent digestibility (DMD) and gas production characteristics generated from the equation $\mathrm{p}=\mathrm{a}+\mathrm{b}\left(1-\mathrm{e}^{-\mathrm{ct}}\right)$, using the three sources of inocula.

\begin{tabular}{|c|c|c|c|c|}
\hline Variable & $n$ & $r$ & Significance & rsd \\
\hline \multicolumn{5}{|c|}{ Rumen liquor from sheep } \\
\hline $\mathrm{a}$ & 24 & 0.44 & 0.0294 & 5.97 \\
\hline $\mathrm{b}$ & 24 & 0.37 & 0.0711 & 6.18 \\
\hline $\mathrm{c}$ & 24 & 0.33 & 0.1146 & 6.29 \\
\hline$(a+b)$ & 24 & 0.18 & 0.4064 & 6.56 \\
\hline$a+b$ & 24 & 0.59 & 0.0122 & 5.53 \\
\hline$a+b+c$ & 24 & 0.59 & 0.0334 & 5.65 \\
\hline$(a+b)+c$ & 24 & 0.34 & 0.2739 & 6.42 \\
\hline \multicolumn{5}{|c|}{ Rumen liquor from bovine } \\
\hline $\mathrm{a}$ & 24 & 0.15 & 0.4953 & 6.60 \\
\hline $\mathrm{b}$ & 24 & 0.11 & 0.5954 & 6.63 \\
\hline $\mathrm{c}$ & 24 & 0.50 & 0.0137 & 5.79 \\
\hline$(a+b)$ & 24 & 0.07 & 0.7474 & 6.65 \\
\hline$a+b$ & 24 & 0.16 & 0.5876 & 6.73 \\
\hline$a+b+c$ & 24 & 0.53 & 0.0788 & 5.93 \\
\hline$(a+b)+c$ & 24 & 0.53 & 0.0307 & 5.78 \\
\hline \multicolumn{5}{|c|}{ Sheep faecal suspension } \\
\hline $\mathrm{a}$ & 24 & 0.30 & 0.1580 & 6.37 \\
\hline $\mathrm{b}$ & 24 & 0.32 & 0.1251 & 6.31 \\
\hline $\mathrm{c}$ & 24 & 0.20 & 0.3495 & 6.53 \\
\hline$(a+b)$ & 24 & 0.42 & 0.0411 & 6.05 \\
\hline$a+b$ & 24 & 0.44 & 0.1049 & 6.13 \\
\hline$a+b+c$ & 24 & 0.46 & 0.1882 & 6.22 \\
\hline$(a+b)+c$ & 24 & 0.43 & 0.1219 & 6.17 \\
\hline
\end{tabular}


with multiple regressions (Tab. V). The same was not observed for silages.

For the method that used sheep rumen liquor, no significant differences were obtained with green fodder or silages (Tab. V). With the method that used suspension of sheep faeces, no significant results were found for green grasses, but some significant differences were found for silages (Tab. V) with $(\mathrm{a}+\mathrm{b})$ and with $(\mathrm{a}+\mathrm{b})+\mathrm{c}$. Mauricio et al. [16] and Altaf et al. [1] reported that faecal material has a potential as an alternative inocula to rumen liquor for in vitro gas production techniques for estimating total gas production in vitro and in vitro organic matter digestibility.

Khazaal et al. [14] reported that gas production methods have important potential in the prediction of animal performance. These authors have observed the highest accuracy for predicting in vivo DM apparent digestibility from gas production, $(\mathrm{a}+\mathrm{b})$, $R^{2}=0.583 ;(\mathrm{a}+\mathrm{b})+\mathrm{c}, R^{2}=0.608$ and $\mathrm{a}+\mathrm{b}+\mathrm{c}, R^{2}=0.784$, when they use 10 graminaceous and leguminous hays. Also Khazaal et al. [15] observed $(a+b)$,
$R^{2}=0.708 ;(\mathrm{a}+\mathrm{b})+\mathrm{c}, R^{2}=0.733$ and $\mathrm{a}+\mathrm{b}+\mathrm{c}, R^{2}=0.738$, when they used 19 samples of graminaceous and leguminous hays.

As it is possible to observe, the gas production method can be used to predict the digestibility of green forages if sheep rumen liquor is used. It is important to note that the results from Khazaal et al. [14] were obtained just with hays. Nagali et al. [20] compared fresh forages and hays and reported that no differences were observed in gas production. Susmel et al. [26] observed that the gas production coefficients were moderately correlated with in vivo dry matter digestibility (highest $r=0.708$ ).

In a study that examined the relationship between in vitro gas production, concomitant in vitro apparent and true DM degradability, Blümmel et al. [3] observed that in vitro gas production and in vitro apparent and true degradability of straw are highly correlated $(P<0.0001), r$ being 0.96 and 0.95 respectively. Gas production alone is never sufficient to predict organic matter digestibility in samples varying in ash, crude

Table V. Relationship between in vivo DM apparent digestibility (DMD) of fresh and ensiled forage and gas production characteristics generated from the equation $\mathrm{p}=\mathrm{a}+\mathrm{b}\left(1-\mathrm{e}^{-\mathrm{ct}}\right)$, using the three sources of inocula.

\begin{tabular}{|c|c|c|c|c|c|}
\hline Forages & Variable & $n$ & $r$ & Significance & rsd \\
\hline \multicolumn{6}{|c|}{ Rumen liquor from sheep } \\
\hline Fresh forage & $a+b+c$ & 12 & 0.92 & 0.0011 & 3.09 \\
\hline Fresh forage & $(a+b)+c$ & 12 & 0.86 & 0.0025 & 3.89 \\
\hline Ensiled forage & $a+b+c$ & 12 & 0.34 & 0.7981 & 5.48 \\
\hline Ensiled forage & $(a+b)+c$ & 12 & 0.21 & 0.8114 & 5.36 \\
\hline \multicolumn{6}{|c|}{ Rumen liquor from bovine } \\
\hline Fresh forage & $a+b+c$ & 12 & 0.55 & 0.3813 & 6.71 \\
\hline Fresh forage & $(a+b)+c$ & 12 & 0.51 & 0.2536 & 6.51 \\
\hline Ensiled forage & $a+b+c$ & 12 & 0.34 & 0.7981 & 5.48 \\
\hline Ensiled forage & $(a+b)+c$ & 12 & 0.21 & 0.8114 & 5.36 \\
\hline \multicolumn{6}{|c|}{ Sheep faecal suspension } \\
\hline Fresh forage & $a+b+c$ & 12 & 0.57 & 0.3388 & 6.59 \\
\hline Fresh forage & $(a+b)+c$ & 12 & 0.42 & 0.4252 & 6.90 \\
\hline Ensiled forage & $a+b+c$ & 12 & 0.72 & 0.1008 & 4.02 \\
\hline Ensiled forage & $(a+b)+c$ & 12 & 0.72 & 0.0366 & 3.80 \\
\hline
\end{tabular}


protein $(\mathrm{CP})$, ether extract (EE), as in the present case, since there is not as much gas from CP/EE as from Carbohydrates. Good results are only obtained for homogenous sample pools, for instance in straw [3] where $\mathrm{CP}$ does not interfere and where dry matter digestibility is only affected by carbohydrate digestibility which is expressed by gas.

The low prediction in silages can be explained by the variability in the preservation levels. Sileshi et al. [24] reported that the use of in vitro gas production parameters in the prediction of rumen dry matter disappearance of forages, depends on the type of forage used. The different phases in the gas production profiles are caused by fermentation of the soluble and non-soluble fractions and by turnover of the microbial population [9].

\section{CONCLUSION}

When comparing the three sources of inocula, it may be concluded that the highest gas production was obtained with the rumen liquor from slaughtered cattle. The use of the sheep faeces suspension gave significantly lower gas production $(P<0.05)$ than the rumen liquor from slaughtered cattle. Statistical differences $(P<0.05)$ were also observed between the results of gas production with rumen liquor from slaughtered cattle and from sheep.

The method that uses sheep rumen liquor can be used to predict the in vivo apparent digestibility in fresh forages. The alternative inocula sources did not allow for a good prediction of in vivo apparent digestibility.

\section{ACKNOWLEDGEMENTS}

The authors express their appreciation to JNICT, PRAXIS XXI and CITA-A for financial support of this research. We also thank Goretti Fagundes and Gilberta Goulart for their excellent technical assistance in the laboratory and Dr J.F. Moreira da Silva for the revision of the text.

\section{REFERENCES}

[1] Altaf U.R., Mauricio R., Mould F.L., Smith T Owen E., Phipps R.H., Theodorou M.K., Comparison of bovine rumen liquor and bovine faeces as sources of microorganisms for the in vitro gas production techniques for assessing silages of maize and maize plant fractions, Proceedings of the British Society of Animal Science, BSAS Annual Winter Meeting, Scarborough, UK, 1998, $60 \mathrm{p}$.

[2] Blümmel B.Y., Ørskov E.R., Comparison of in vitro gas production and nylon bag degradability of roughages in predicting feed intake in cattle, Anim. Feed Sci. Technol. 40 (1993) 109-119.

[3] Blümmel B.Y., Steingass H., Becker K., The relationship between in vitro gas production, in vitro microbial biomass yield and $15 \mathrm{~N}$ incorporation and its implications for the prediction of voluntary feed intake of roughages, Brit. J. Nutr. 77 (1997) 911-921.

[4] Borba A.E.S., Gonçalves L.M.O., A comparison of three sources of inocula in the gas production method as predictors of the in vivo apparent digestibility, 47th Annual Meeting of the European Association for Animal Production, Lillehammer, Norway, 1996, 78 p.

[5] Borba A.E.S., Ramalho Ribeiro J.M.C., Valor nutritivo do azevém verde e ensilado, em três fases de desenvolvimento, Rev. Portuguesa Zoot. 1 (1994) 63-75

[6] Borba A.E.S., Ramalho Ribeiro J.M.C., Variação do valor nutritivo e da degradabilidade in situ da matéria seca e da proteína bruta do milho com a época de corte e com o método de conservação, Rev. Ciên. Agr. 18 (1995) 35-47.

[7] Borba A.E.S., Ramalho Ribeiro J.M.C., Nutritive value and in situ dry matter and protein degradation of green and ensiled oats at three stage of growth, Rev. Portuguesa Zoot. 3 (1996) 55-66.

[8] Borba A.E.S., Ramalho Ribeiro J.M.C., Nutritive value and in situ dry matter and protein degradability of fresh and ensiled Italian ryegrass at three stage of growth, Arquipélago, Life and Marine Sciences 14A (1996) 85-94.

[9] Cone J.W., van Gelder A.H., Driehuis F., Description of gas production profiles with a three-phasic model, Anim. Feed Sci. Technol. 66 (1997) 31-45.

[10] El Shaer H.M., Omed H.M., Chamberlain A.G., Axford R.F.E., Use of faecal organisms from sheep for the in vitro determination of digestibility, J. Agric. Sci. (Camb.) 109 (1987) 257-259.

[11] Gonçalves L.M.B.O., Borba A.E.S., Study of gas production capacity by three sources of inocula, J. Agric. Sci. (Camb.) 127 (1996) 511-515

[12] Herrero M., Fawcett R.H., Dent J.B., Seasonal differences in the metabolizable energy concentration of kikuyu grass as predicted from in vitro gas production measurements, Ann. Zootech. 44 (Suppl.) (1995) 46. 
[13] Lana R.P., Russel J.B., Van Amburgh E., The role of $\mathrm{pH}$ in regulation ruminal methane and ammonia production, J. Anim. Sci. 76 (1998) 2190-2196.

[14] Khazaal K., Dentinho M.T., Ribeiro J.M., Ørskov E.R., A comparison of gas production during incubation with rumen contents in vitro and nylon bag degradability as predictors of the apparent digestibility in vivo and the voluntary intake of hays, Anim. Prod. 57 (1993) 105-112.

[15] Khazaal K., Dentinho M.T., Ribeiro J.M. Ørskov E.R., Prediction of apparent digestibility and the voluntary intake of hays fed to sheep: comparison between using fibre components in vitro digestibility or characteristics of gas production or nylon degradation, Anim. Sci. 61 (1995) 527-538.

[16] Mauricio R., Abdalla A.L., Mould F.L., Altaf U.R., Smith T., Owen E., Givens D.I., Dhanoa M.S., Theodorou M.K., Comparison of bovine rumen liquor and faeces as sources of microorganisms for the in vitro gas production technique for assessed silages using twelve gramminaceous forages, Proceedings of the British Society of Animal Science, BSAS Annual Winter Meeting, Scarborough, UK, 1998, $60 \mathrm{p}$.

[17] Mauricio R.M., Mould F.L., Dhanoa M.S . Owen E., Channa K.S., Theodorou M.K., A semi-automated in vitro gas production technique for ruminant feedstuff evaluation, Anim Feed Sci. Technol. 79 (1999) 321-330.

[18] McDonald I., A revised model for the estimation of protein degradability in the rumen, J. Agric. Sci. (Camb.) 96 (1981) 251-252.

[19] Menke K.H., Raab L., Salewski A., Steingass H., Fritz D., Schneider W., The estimation of the digestibility and metabolizable energy content of ruminant feedingstuffs from the gas production where then are incubated with rumen liquor in vitro, J. Agric. Sci. (Camb.) 93 (1979) 217-222.
[20] Nagadi S., Herrero M., Jessop N.S., A comparison of the gas production profiles of fresh and dry forage, Proceedings of the British Society of Animal Science, BSAS Annual Winter Meeting, Scarborough, UK, 1998, 62 p.

[21] Nikolic' J.A., Jovanovic M., Zeremski D., Application of a modified in vitro procedure in the prediction of organic matter digestibility of feedstuffs for ruminants, Acta Vet. (Beograd) 37 (1987) 3-12.

[22] Ørskov E.R., McDonald I., The estimation of protein degradability in the rumen from incubation measurements weighted according rate of passage, J. Agric. Sci. (Camb.) 92 (1979) 499-503.

[23] Omed H.M., Axford R.F.E., Chamberlain A.G., Givens D.I., A comparison of three laboratory techniques for the estimation of the digestibility of feedstuffs for ruminants, J. Agric. Sci. (Camb.) 113 (1989) 35-39.

[24] Sileshi Z., Owen E., Dhanoa M.S., Theodorou M.K., Prediction of in situ rumen dry matter disappearance of Ethiopian forages from a in vitro gas production technique using a pressure transducer, chemical analyses or in vitro digestibility, Anim. Feed Sci. Technol. 61 (1996) 73-87.

[25] Steel R.G.D., Torrie J.H., Principles and Procedure of Statistics, Second Edition, McGrawHill Book Company, USA, 1980.

[26] Susmel P., Mills C.R., Spanghero M., Stefanon B., The prediction of the nutritive value and degradability of Mediterranean forages by in vitro gas production, Zootech. Nutr. Anim. 21 (Suppl. 6) (1995) 135-142.

[27] Theodorou M.T., Williams B.A., Dhanoa M.S McAllan A.B., France J., A simple gas production method using a pressure transducer to determine the fermentation kinetics of ruminant feeds, Anim. Feed Sci. Technol. 48 (1994) 185-197. 